\title{
Flotation enrichment of resistant gold ores
}

\author{
Gulzhan Askarova ${ }^{1, *}$, Mels Shautenov ${ }^{1}$, and Kulzhamal Nogaeva ${ }^{2}$ \\ ${ }^{1}$ Kazakh National Research Technical University named after K. I. Satpayev, 050000, Almaty, \\ Satpayev Str. 22, Republic of Kazakhstan \\ ${ }^{2}$ Kyrgyz state University, of geology, mining and development of natural resources named after \\ academician Usengazy Asanalie, 720001, Bishkek, Chui Ave., 215, Republic of Kyrgyzstan
}

\begin{abstract}
Ores of the Vasilkovsky deposit include arsenopyrite, pyrite, pyrrhotite, marcasite, gold, chalcopyrite, sphalerite, galena, faded ore (tennantite), bismuthine, native bismuth, lellingite, molybdenite, cubanite, bornite, antimonite, relict minerals, magnetite, apatite and apatite chromite, sericite, chlorite, potassium feldspar, tourmaline), quartz, carbonates (siderite, ankerite, calcite), fluorite, barite. Arsenopyrite is the main ore mineral. It contains the bulk of gold, as well as impurities - copper, cobalt, nickel, bismuth, zirconium, titanium, lead, zinc, antimony, silver, molybdenum. Bismuth and its minerals are widespread, they are constantly associated with arsenopyrite, forming intergrowths with native gold, less often with chalcopyrite and faded ore. Native gold is distributed very unevenly, forms the finest precipitates ranging in size from tenths of a micron to $0.063 \mathrm{~mm}$, grows together with quartz, arsenopyrite, pyrite and bismuth minerals. Rich ores were formed by combining bismuthcontaining associations with arsenopyrite. The role of gold in arsenopyrite increases with depth. Ores are of the gold-quartz-sulfide type. Quartz in ore up to $90 \%$, sulfides - from 3 to $5 \%$. The content of harmful impurities (arsenic) reaches $2 \%$ or more. Ores are refractory, require special technology for the beneficiation and extraction of gold.
\end{abstract}

\section{Introduction}

Gold in ores is present in more than 20 mineral forms, but native gold is mainly of industrial importance, represented by metal particles of various sizes, composition, shape and structure with many minerals, most often with quartz, pyrite, arsenopyrite, and barite. Tellurides, sulfides, organometallic, sorbed, water-soluble and other gold compounds are much less commonly present. The chemical composition of native gold is not very constant. Of the geochemical properties for gold, the most characteristic are: siderophilic (connection with elements of the iron family); chalcophilic (connection with six chemical elements, analogues of sulfur and arsenic); lithophilic (its hydroxide forms, usually in a colloidal state); biophilic (its concentration in connection with organic matter); neutral (all its native forms of finding), etc. Typical impurities in native gold are silver, copper, iron, arsenic, bismuth, tellurium, selenium, manganese, lead, palladium, platinum and other elements that form isomorphic mixtures or surface films ("shirts"). The native gold content is 75-90\% [1, 2].

\footnotetext{
"Corresponding author: askarova_guljan@mail.ru
} 
At present, the main difficulties of the gold mining industry in Russia are associated with the extraction and processing of refractory hard and poor gold-bearing ores and technogenic raw materials, characterized by a high content of finely divided gold up to micro and nanoscale. Gold flotation is used for refractory gold-bearing ores and products containing 1-3 g/t of gold. During flotation processing of polymetallic ores, gold is simultaneously recovered in appropriate concentrates (copper, zinc, etc.). The extraction of gold into copper and zinc concentrates is from 30 to $35 \%$, the remaining gold goes into pyrite concentrate and $10-15 \%$ into dump tailings.

We have established the optimal regime of the flotation enrichment scheme. Research on the development of technology for recovery of gold from refractory ores was made on three samples of Vasilkovskoye stockwork deposits.

In this case, various combinations of the special flotation and hydrometallurgy processes are used, in particular in combination with sulfidation processes with the aim of converting minerals from the oxidized form (sulfates, carbonates) to easily floated sulfide. Combined processes for the processing of oxidized and mixed ores, for example, use a combination of flotation processes.

The aim of the research is the selection and justification of the combined gravityflotation method of enrichment of refractory gold-bearing raw materials and the hydro and pyrometallurgical method of processing enrichment products based on the study of the technological properties of the feedstock and enrichment products.

\section{Methods}

The properties of impurity gold differ from the properties of pure gold: impurities reduce the density of gold particles, change the structure, gold becomes less noble in chemical terms. Impurities of iron give gold magnetic properties. Differences in gold composition are noticeably manifested in flotation. Impurities reduce the flotation ability of gold, and the more, the easier they are oxidized. Often, gold particles have surface coatings consisting of oxides of iron and manganese, acanthite, covellite, galena, kaolinite and some other minerals. Coatings, besides natural origin, also appear as a result of mechanical grinding of the gold surface with solid particles during grinding. As a rule, gold with coatings floats worse than gold with a clean surface [2].

The forms of gold release are the most diverse: disseminated, vein-interspersed, vein, spongy, dendritic, scaly, lamellar-nodosum, in oxidized films, porous, magnetic, in intergrowths and others. Flaky and scaly particles float better.

Given the behavior in technological operations, gold particles size is divided into large (larger than 70 microns), small (smaller than 70, but larger than $1 \mathrm{~mm}$ ) and finely dispersed (smaller than $1 \mathrm{~mm}$ ). It is advisable to isolate very large (larger than 0.5-0.6 mm), and in finely dispersed - colloidal or submicroscopic (finer than $0.1 \mathrm{~mm}$ ) [2].

The work was carried out using a complex of experimental and analytical research methods, including mathematical modeling methods using computers, mathematical statistics, physical modeling, experimental studies on various scale models and technological studies under production conditions. Physical, physicochemical methods were used in experimental studies Chemical and flotation methods: flotation 'laboratory and industrial tests on ores of various substance.

\section{Experimental research}

Development of flotation scheme of enrichment. The selection of the flotation enrichment mode for ore samples 1 and 3 was carried out by the method of the planned 
experiment (steep ascent) with variables: grinding size, consumption of butyl xanthogenate and foamer T-66 and T-80, consumption of copper sulfate and soda. A fractional replica of the four-and five-factor experiment was implemented. According to the results of the experiments, it was found that it is not possible to obtain flotation tails of the initial ore of sample 1 with a gold content less than $1.0 \mathrm{~g} / \mathrm{t}$ at a grinding size of ore up to $80-85 \%$ and less than $0.074 \mathrm{~mm}$. The yield of flotation concentrate depends on the flow rate of the foamer and was $8-12 \%$. In the enlarged experiment (Fig. 1) the following results were obtained when returning the industrial product of primary flotation concentrate and 11th flotation concentrate: At the expense of the 1st flotation: T-80$50 \mathrm{~g} / \mathrm{t}$; Xanthogenate $-175 \mathrm{~g} / \mathrm{t}$.

During the 11 th flotation $\mathrm{T}-80-50 \mathrm{~g} / \mathrm{t}$, xanthogenate $-175 \mathrm{~g} / \mathrm{t}$ and $80 \%$ grinding fineness class less than $0.074 \mathrm{~mm}$ flotation concentrate yield was 11.75 with a gold content of $77.8 \mathrm{~g} / \mathrm{t}$ and the extraction of gold concentrate $90.7 \%$. The gold content in the flotation tails was $1.0 \mathrm{~g} / \mathrm{t}$. Analysis of gold losses in flotation tailings by size classes showed that more than $60 \%$ of all gold losses occur in classes larger than 40 microns. At the output of these classes $43.81 \mathrm{~g} / \mathrm{t}$, the content of gold in them was $1.45 \mathrm{~g} / \mathrm{t}$, and the loss of gold with them is $61.55 \%$. The distribution of gold by size classes of sedimentation analysis of flotation tailings of sample 1 is presented in Table 1.

Table 1. Distribution of gold by classes of sedimentation analysis of flotation tails.

\begin{tabular}{|c|c|c|c|}
\hline $\begin{array}{c}\text { Classes, } \\
\mathrm{mm}\end{array}$ & $\begin{array}{c}\text { Output, } \\
100 \%\end{array}$ & $\begin{array}{c}\text { Gold content, } \\
\mathrm{g} / \mathrm{t}\end{array}$ & $\begin{array}{c}\text { Division, } \\
100 \%\end{array}$ \\
\hline+60 & 24.63 & 1.8 & 41.7 \\
\hline$-60+40$ & 19.18 & 1.1 & 19.85 \\
\hline$-40+20$ & 18.60 & 0.65 & 11.37 \\
\hline$-20+0$ & 37.59 & 0.5 & 27.08 \\
\hline Total & 100 & 4.05 & 100 \\
\hline
\end{tabular}

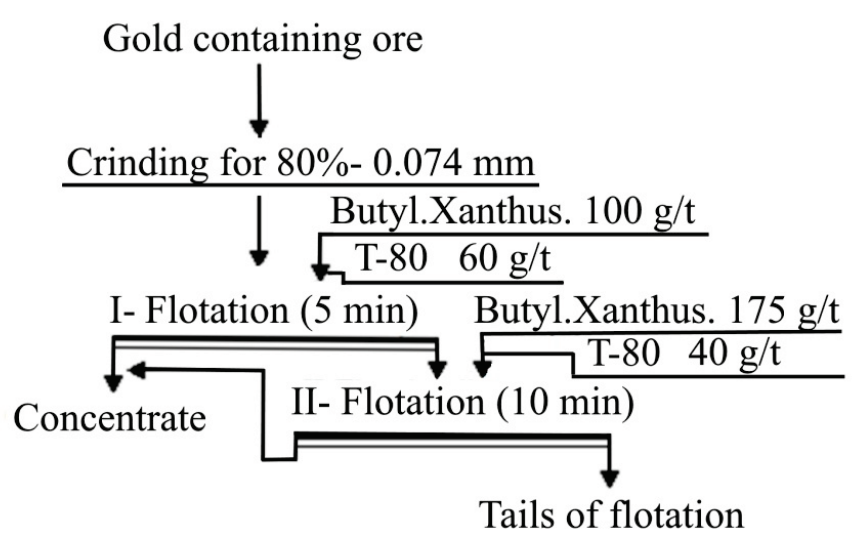

Fig. 1. Scheme of balance experiments in single-stage grinding.

For sample 2 ore, flotation enrichment studies were conducted on gravity tailings with a gold content of $2.4 \mathrm{~g} / \mathrm{t}$ according to the method of the planned experiment (steep ascent), a fractional replica of the four-factor experiment with variables was implemented:

1) Size of grinding in the class is smaller than $0.074 \mathrm{~mm}(\mathrm{X} \mathrm{1})$;

2) Consumption of the foamer T-80 (H2);

3) consumption of butyl xanthogenate (H3);

4) Consumption of copper sulfate (X 4). 
The matrix of experiment planning is given in Table 2, the scheme of experiments is presented in Figure 1, the conditions of the experiments are given in Ttable 2, and the results are given in Table 4. according to this Table, the results of the splanned experiments were processed [1-8].

Table 2. Matrix planning of experiments on the flotation [8-14].

\begin{tabular}{|c|c|c|c|c|}
\hline \multirow[t]{2}{*}{ Indicators } & \multicolumn{4}{|c|}{ Variable factor } \\
\hline & $\begin{array}{c}\text { Size of } \\
\text { grinding } \% \text {, } \\
\text { smaller than } \\
0.074 \text { CL. }\end{array}$ & $\begin{array}{c}\text { Extraction, } \\
\mathrm{g} / \mathrm{t}\end{array}$ & $\begin{array}{c}\text { Butyl } \\
\text { xanthogenate, } \\
\mathrm{g} / \mathrm{t}\end{array}$ & $\begin{array}{c}\text { Copper } \\
\text { sulphate, } \\
\mathrm{g} / \mathrm{t}\end{array}$ \\
\hline Basic level & 75 & 60 & 125 & 75 \\
\hline $\begin{array}{l}\text { The range of } \\
\text { variation in }\end{array}$ & 10 & 20 & 25 & 75 \\
\hline Top level & 85 & 80 & 150 & 150 \\
\hline Lower level & 65 & 40 & 100 & 0 \\
\hline $\begin{array}{l}\text { № samples } \\
\text { experiments }\end{array}$ & & & & \\
\hline 159 & - & - & - & - \\
\hline 160 & + & - & - & - \\
\hline 161 & - & + & - & - \\
\hline 162 & + & + & + & - \\
\hline 163 & - & - & + & + \\
\hline 164 & + & - & + & + \\
\hline 165 & - & + & - & + \\
\hline 166 & + & + & + & + \\
\hline
\end{tabular}

Table 3. Conditions for conducting experiments [8-14].

\begin{tabular}{|c|c|c|c|c|}
\hline \multirow{2}{*}{$\begin{array}{c}\text { № samples } \\
\text { experiments }\end{array}$} & $\begin{array}{c}\text { Size of } \\
\text { grinding \%, } \\
\text { smaller than } \\
0.074 \text { CL. }\end{array}$ & \multicolumn{3}{|c|}{ Reagent consumption, g/t } \\
\cline { 3 - 5 } & 65 & 40 & $\begin{array}{c}\text { Butyl } \\
\text { xanthogenate }\end{array}$ & $\begin{array}{c}\text { Copper } \\
\text { sulphate }\end{array}$ \\
\hline 159 & 85 & 40 & 100 & 0 \\
\hline 160 & 65 & 80 & 100 & 0 \\
\hline 161 & 85 & 80 & 150 & 0 \\
\hline 162 & 65 & 40 & 150 & 150 \\
\hline 163 & 85 & 40 & 150 & 150 \\
\hline 164 & 65 & 80 & 100 & 150 \\
\hline 165 & 85 & 80 & 150 & 150 \\
\hline 166 & 65 & 80 & 100 & 0 \\
\hline 167 & 85 & 40 & 150 & 150 \\
\hline 168 & 65 & 40 & 150 & 150 \\
\hline 169 & 85 & 80 & 150 & 150 \\
\hline 170 & & & & \\
\hline
\end{tabular}


Grinding for 80\%- $0.074 \mathrm{~mm}$

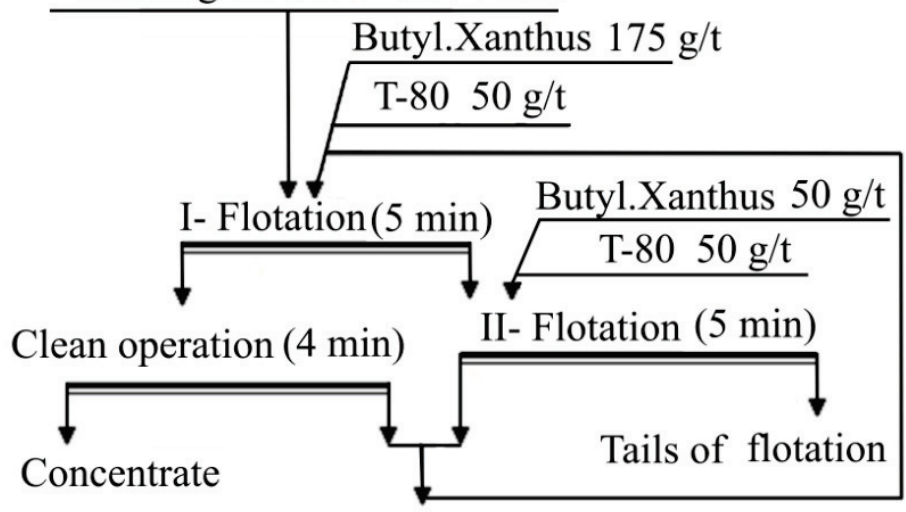

Fig. 2. Scheme of the experiments on the flotation.

Table 4. Results of experiments performed on the experiment planning matrix [9-15].

\begin{tabular}{|c|c|c|c|c|c|}
\hline $\begin{array}{l}\text { № experiment } \\
\text { numbers }\end{array}$ & Products & $\begin{array}{c}\text { Output, } \\
\%\end{array}$ & $\begin{array}{c}\text { Gold } \\
\text { content, } \mathrm{g} / \mathrm{t}\end{array}$ & $\begin{array}{l}\text { Weight of } \\
\text { gold, g/t }\end{array}$ & $\begin{array}{c}\text { Division, } \\
\%\end{array}$ \\
\hline \multirow[t]{3}{*}{1} & Concentrate & 5.81 & 25.1 & 1.458 & 60.72 \\
\hline & Tails & 94.19 & 1.0 & 0.942 & 39.24 \\
\hline & Source & 100 & 2.4 & 2.4 & 100 \\
\hline \multirow[t]{3}{*}{2} & Concentrate & 5.88 & 24.8 & 1.459 & 60.78 \\
\hline & Tails & 94.12 & 1.0 & 0.941 & 39.22 \\
\hline & Source & 100 & 2.4 & 2.4 & 100 \\
\hline \multirow[t]{3}{*}{3} & Concentrate & 6.81 & 22.91 & 1.56 & 65.0 \\
\hline & Tails & 93.19 & 0.9 & 0.84 & 35.0 . \\
\hline & Source & 100 & 2.4 & 2.4 & 100 \\
\hline \multirow[t]{3}{*}{4} & Concentrate & 8.5 & 16.4 & 1.3935 & 58.06 \\
\hline & Tails & 91.5 & 1.1 & 1.0065 & 41.94 \\
\hline & Source & 100 & 2.4 & 2.4 & 100 \\
\hline \multirow[t]{3}{*}{5} & Concentrate & 9.63 & 13.7 & 1.316 & 54.83 \\
\hline & Tails & 90.37 & 1.2 & 1.084 & 45.17 \\
\hline & Source & 100 & 2.4 & 2.4 & 100 \\
\hline \multirow[t]{3}{*}{6} & Concentrate & 8.79 & 20.0 & 1.762 & 73.42 \\
\hline & Tails & 91.21 & 0.7 & 0.638 & 26.58 \\
\hline & Source & 100 & 2.4 & 2.4 & 100 \\
\hline \multirow[t]{3}{*}{7} & Concentrate & 9.94 & 16.0 & 1.59 & 66.25 \\
\hline & Tails & 90.06 & 0.9 & 0.81 & 33.75 \\
\hline & Source & 100 & 2.4 & 2.4 & 100 \\
\hline \multirow[t]{3}{*}{8} & Concentrate & 9.27 & 17 & 1.58 & 65.8 \\
\hline & Tails & 90.73 & 0.9 & 0.82 & 34.2 \\
\hline & Source & 100 & 2.4 & 2.4 & 100 \\
\hline \multirow[t]{5}{*}{9} & Concentrate & 6.55 & 19.5 & 1.279 & 53.29 \\
\hline & Tails & 93.45 & 1.2 & 1.121 & 46.71 \\
\hline & Source & 100 & 2.4 & 2.4 & 100 \\
\hline & Tails & 90.41 & 0.9 & 0.81 & 33.9 \\
\hline & Source & 100 & 2.4 & 2.4 & 100 \\
\hline
\end{tabular}


Table 4 (continued). Results of experiments performed on the experiment planning matrix [9-15].

\begin{tabular}{|c|l|c|c|c|c|}
\hline $\begin{array}{c}\text { № experiment } \\
\text { numbers }\end{array}$ & Products & $\begin{array}{c}\text { Output, } \\
\%\end{array}$ & $\begin{array}{c}\text { Gold } \\
\text { content, g/t }\end{array}$ & $\begin{array}{c}\text { Weight of } \\
\text { gold, g/t }\end{array}$ & $\begin{array}{c}\text { Division, } \\
\%\end{array}$ \\
\hline \multirow{2}{*}{10} & Concentrate & 8.4 & 11.1 & 0.934 & 38.92 \\
\cline { 2 - 6 } & Tails & 91.6 & 1.6 & 1.466 & 61.08 \\
\cline { 2 - 6 } & Source & 100 & 2.4 & 2.4 & 100 \\
\hline \multirow{2}{*}{11} & Concentrate & 8.76 & 17.0 & 1.488 & 61.98 \\
\cline { 2 - 6 } & Tails & 91.24 & 1.0 & 0.912 & 38.02 \\
\cline { 2 - 6 } & Source & 100 & 2.4 & 2.4 & 100 \\
\hline & Concentrate & 9.59 & 11.8 & 1.59 & 66.1 \\
\hline
\end{tabular}

\section{Results and discussion}

The reproducibility of experiments is estimated by variance

$$
\sigma_{x}^{2}=\frac{\sum_{i=1}^{n}\left(X_{i}-X^{\leftarrow}\right)}{N-1},
$$

where $X^{\leftarrow}$ is the average value of the optimization parameter; $X_{i}$ is the value of the optimization parameter of an individual repetition; $N$ is the number of experiments.

Table 5. Variance of experiments (has been compiled to calculate the variance).

\begin{tabular}{|cc|c|c|c|c|}
\hline \multicolumn{2}{|c|}{ № samples } & $\mathrm{E}_{1}$ & $\mathrm{E}_{2}$ & $\mathrm{E}_{1}+\mathrm{E}_{2} / 2$ & $\sigma_{x}^{2}$ \\
\hline 159 & 60.76 & - & 60.76 & - \\
\hline 160 & 60.78 & - & 60.78 & - \\
\hline 161 & 167 & 65.0 & 53.29 & 59.15 & 68.44 \\
\hline 162 & & 58.06 & - & 58.056 & - \\
\hline 163 & 168 & 54.83 & 38.92 & 46.88 & 126.405 \\
\hline 164 & 169 & 73.42 & 61.98 & 67.7 & 65.37 \\
\hline 165 & & 66.25 & - & 66.25 & - \\
\hline 166 & 170 & 65.8 & 66.1 & 65.95 & 0.045 \\
\hline & & & $\sum=481.53$ & $\sum=260.26$ \\
\hline
\end{tabular}

$\mathrm{E}_{1}$ is distribution as a percentage of concentrate in the first group of experiments, $\mathrm{E}_{2}$ is distribution as a percentage of concentrate in the second group.

The reproducibility of experiments is estimated by the Cochran criterion. The calculated Cochran's criterion is:

$$
\frac{\sigma_{\max }^{2}}{\Sigma \sigma_{x}^{2}}=\frac{126.405}{260.26}=0.49,
$$

where $\sigma_{\max }^{2}$ - maximum dispersion, $\Sigma \sigma_{x}^{2}$ - sum of all variances.

Table criterion for confidence interval $95 \%=0.96$. Since the results are reproducible. The coefficient of the regression equation are found by the formula

$$
b_{i}=\frac{\sum_{i=1}^{N} \varepsilon_{i}}{N},
$$


where $N$ is the number of experiments; $\sum_{i=1}^{N} \varepsilon_{i}$ is the sum of the values of the optimization parameters (gold extraction).

$$
\begin{aligned}
& b_{0}=\frac{60.76+60.78+59.15+58.06+46.88+67.7+66.25+65.95}{8}=59.69 \\
& b_{1}=\frac{-60.76+60.78-59.15+58.06-46.88+67.7-66.25+65.95}{8}=2.43 \\
& b_{2}=\frac{-60.76-60.78+59.15+58.06-46.88-67.7+66.25+65.95}{8}=1.66 \\
& b_{3}=\frac{-60.76-60.78-59.15+58.06+46.88+67.7-66.25+65.95}{8}=-1.04 \\
& b_{4}=\frac{-60.76-60.78-59.15-58.06+46.88+67.7+66.25+65.95}{8}=1.0
\end{aligned}
$$

Regression equation:

$$
\varepsilon=59.69+2.43 X_{1}+1.66 X_{2}-1.04 X_{3}+1.0 X_{4},
$$

where $\mathrm{n}$ is the number of repeated experiments.

Confidence coefficients equation

$$
\begin{gathered}
\sigma_{b_{i}}^{2}=\frac{\sigma_{\varepsilon}^{2}}{N}=\frac{65.06}{8}=8.13 \\
\sigma_{(b)_{i}}=\sqrt{8.13}=2.85 \quad \text { so then } \sigma_{(b) i}=\frac{\sqrt{2.85}}{\sqrt{4}}=1.43 .
\end{gathered}
$$

It shows that all calculated coefficients at variables $X_{1} ; X_{2} ; X_{3} ; X_{4}$ are insignificant, i.e. experiments on flotation were put in an optimum (stationary) mode. Therefore, in order to increase gold recovery by flotation, it is necessary to study other options, for example, with finer ore grinding or stadium flotation. In this direction, the following experiments were made: flotation of the initial ore and stadium flotation [8-12].

Flotation of the initial ore is finer grinding than it was accepted in the formulation of the planned experiments $85 \%$ of the class $0.074 \mathrm{~mm}$ (Table 4 ). The results of the experiments are presented in Table 5, the consumption of the T-80 foamer was increased to $110 \mathrm{~g} / \mathrm{t}$, xanthegenate to $175 \mathrm{~g} / \mathrm{t}$, the duration of flotation up to 25 minutes [12-17].

Table 6. Effect of ore grinding size on gold recovery by flotation.

\begin{tabular}{|l|l|c|c|c|c|}
\hline $\begin{array}{l}\text { № } \\
\text { samples }\end{array}$ & Products & $\begin{array}{c}\text { Output, } \\
\%\end{array}$ & $\begin{array}{c}\text { Gold } \\
\text { content, } \mathrm{g} / \mathrm{t}\end{array}$ & $\begin{array}{c}\text { Division, } \\
\%\end{array}$ & $\begin{array}{c}\text { The content of the class } \\
\text { less than } 0.074 \mathrm{~mm}, \%\end{array}$ \\
\hline \multirow{3}{*}{13} & Concentrate & 8.15 & 36.5 & 78.24 & 90.15 \\
\cline { 2 - 6 } & Tails & 91.85 & 0.9 & 21.76 & \\
\cline { 2 - 6 } & Source & 100 & 3.8 & 100 & \\
\hline \multirow{3}{*}{14} & Concentrate & 9.25 & 32.8 & 79.51 & 93.5 \\
\cline { 2 - 6 } & Tails & 90.75 & 0.9 & 21.49 & \\
\cline { 2 - 6 } & Source & 100 & 3.8 & 100 & \\
& & & & & \\
\hline
\end{tabular}


Table 6 (continued). Effect of ore grinding size on gold recovery by flotation.

\begin{tabular}{|l|l|c|c|c|l|}
\hline $\begin{array}{l}\text { № } \\
\text { samples }\end{array}$ & Products & $\begin{array}{c}\text { Output, } \\
\%\end{array}$ & $\begin{array}{c}\text { Gold } \\
\text { content, } \mathrm{g} / \mathrm{t}\end{array}$ & $\begin{array}{c}\text { Division, } \\
\%\end{array}$ & $\begin{array}{l}\text { The content of the class } \\
\text { less than } 0.074 \mathrm{~mm}, \%\end{array}$ \\
\hline \multirow{3}{*}{15} & Concentrate & 9.56 & 32.2 & 80.97 & \\
\cline { 2 - 6 } & Tails & 90.44 & 0.8 & 19.03 & \\
\cline { 2 - 6 } & Source & 100 & 3.8 & 100 & \\
\hline \multirow{3}{*}{16} & Concentrate & 10.95 & 29.0 & 84.59 & \\
\cline { 2 - 7 } & Tails & 89.05 & 0.7 & 26.41 & \\
\cline { 2 - 7 } & Source & 100 & 3.8 & 100 & \\
\hline
\end{tabular}

\section{Conclusion}

1. The obtained results show that with an increase in the Tonina of ore grinding, the gold content in the flotation tails decreases to $0.7 \mathrm{~g} / \mathrm{t}$. However, it is not possible to obtain flotation tails that are dump-like in terms of gold content. The maximum recovery of gold into concentrate was $84.59 \%$.

2. High-level experience in multi-stage flotation were delivered high-level experience in multi-stage flotation. The results of the consolidated experience are presented in Table 6 .

3. The consolidated (balance) experiment according to the scheme in Figure 1 was performed under the following conditions:

- the size of the grinding of gravity tails in the 1 st flotation- $65 \% \mathrm{CL}$. smaller than $0.074 \mathrm{~mm}$;

- fineness of the tailings of the 2 nd flotation $77.9 \% \mathrm{CL}$. finer than $0.050 \mathrm{~mm}$;

- the mode of the 1 st flotation:

- duration of flotation - $5 \mathrm{~min}$;

-consumption of T-80 - $60 \mathrm{~g} / \mathrm{t}$;

- consumption of xanthogenate $-75 \mathrm{~g} / \mathrm{t}$;

- the mode of the 2 nd flotation:

- duration of flotation - $10 \mathrm{~min}$;

- consumption $\mathrm{T}-80-20 \mathrm{~g} / \mathrm{t}$;

- consumption of xanthogenate $-25 \mathrm{~g} / \mathrm{t}$;

-3 rd flotation mode:

- duration of flotation - $15 \mathrm{~min}$;

- consumption T-80 - $20 \mathrm{~g} / \mathrm{t}$;

- consumption of xanthogenate $-50 \mathrm{~g} / \mathrm{t}$.

The research was carried out within the framework of the Project GF MES RK «Research and instrumentation of the processing technology of refractory arsenic-sulfide gold-bearing ore of the Kazakhstan deposit» №0210PK00912

\section{Reference}

1. Taggart, A.F. (1933). Handbook of mineral processing. M.-L.: State scientific and technical mining and geological and petroleum publishing house, 1933

2. O.S. Bogdanova. Handbook of ore dressing. Main processes. (1983). Mocow: Nedra

3. L.V. Chugayev. (1987). Metallurgy of precious metals. Mocow: Metallurgy

4. Kotlyar, Y.A., Meretukov M.L. (2002). Metallurgy of precious metals.- Moskow: Metallurgy

5. Meretukov, I.N., Orlov, A.M. (1991). Metallurgy of noble metals. Foreign experience. Moscow: Metallurgy 
6. Ladeishikov, V.V. (1968). Extraction of gold from refractory ores and concentrates. Moscow: Nedra

7. Ladeishikov, V.V. (1999). Technology of extracting gold and silver from refractory ores. Irkutsk: JSC "Irgiredmet".

8. Zelenov, V.I. (1978). Methods of research of gold-bearing ores. Moskow: Nedra

9. Nalimov, V.V., Chernova, N.A. (1965). Statistical methods of planning extreme experiments. Moscow: Nauka.

10. Shokhin, V.N., Lopatin, A.G. (1993). Gravitational methods of mineral enrichment. Moscow: Nedra.

11. Raivich, I.D. (1985). Gravitational enrichment of crushed ores of non-ferrous metals and calculation of the results of their gravitational enrichment. Textbook. Alma-ATA

12. Raivich, I. D. (1981). Methodical guide to research works of students. Almaty: The Kazakh Polytechnic Institute

13. Tsarkov, V.A. (2004). Experience of gold mining enterprises of the world. Moskov: Izdat.house "Ore and metals"

14. Alexandrova, T.N., Romashev, A.O., Semenikhin, D.N. (2015). Mineralogical and technological aspects and perspective methods of intensification of sulfide gold ore enrichment. Scientific-technical and production journal "Metallurg". 4, 53-59

15. Alexandrova, T.N., Tsyplakov, V.N., Aksenov, B.V., Romashev, A.O., Semenikhin D. N. (2015). Technologies of removal of sorption-active carbonaceous substances from persistent gold sulfide ores and concentrates of the Mayskoye Deposit. Scientific and technical journal "Ore Enrichment", 4, 3-7

16. Development of new combined technologies and improvement of existing technologies of processing of hard-to-enrich ores: report on research (interim). (2009). KazNTU, ruk. Soutenu M. P. State registration No. 0109101490

17. Research and hardware design of technology of processing of persistent arsenic-sulfide gold ore of Kazakhstan Deposit. (2010). Report on research (interim). KazNTU, ruk. Soutenu M. R. State registration No. 0110RK00366, No. 0210RK00912 